\title{
MALOPOLSKI HORSES - SPORT OR RECREATION?
}

\section{KONIE MAŁOPOLSKIE - SPORT CZY REKREACJA?}

\section{Departament of Genetics and Horse Breeding, Siedlce University of Natural Sciences} and Humanities, Poland

\begin{abstract}
Streszczenie. Aktualne wielu hodowców boryka się z problemem ukierunkowania hodowli na potrzeby sportowe i z coraz większymi wymaganiami w stosunku do wierzchowców. Wiele wybrakowanych koni, niespełniających wymagań wykwalifikowanych jeźdźców, trafia do amatorów, którzy nie radzą sobie z tymi zwierzętami. Na podstawie informacji uzyskanych z list startowych Mistrzostw Polski Młodych Koni (MPMK) z lat 2010-2015 oceniono, jaki udział spośród wszystkich startujących ras koni hodowli polskiej stanowiły konie małopolskie, oraz przeanalizowano osiągnięcia sportowe koni małopolskich, z uwzględnieniem płci oraz dolewu pełnej krwi angielskiej startujących osobników. Liczba koni małopolskich startujących w Mistrzostwach Polski Młodych Koni stanowi niespełna 10\%; poziom ten utrzymał się na wyrównanym poziomie przez 5 analizowanych lat; najmniej koni małopolskich odnotowano w roku 2014 (6,7\%); rok później ich liczba wzrosła do 9,6\%. Wieloletnia praca hodowców nad rasą koni małopolskich jest bezcenna, dlatego konieczne jest kontynuowanie tej tradycji poprzez doskonalenie cech i zachowanie formy pierwotnej konia małopolskiego. Doskonalenie to musi opierać się na doskonałym materiale popartym pracą hodowlaną sektora państwowego i sektora prywatnego.
\end{abstract}

Key words: Malopolski horses, breeding, sport, Polish Championships for Young Horses.

Słowa kluczowe: konie małopolskie, hodowla, sport, Mistrzostwa Polski Młodych Koni.

\section{OUTLINE OF THE PROBLEM}

In the past, breeding of Polish Half Bred horses in Europe remained at a high level. Polish armies fighting at Napoleon's side were among the few to return from Moscow on horseback, because only Polish horses were able to withstand the rigours of the arduous expedition. Horses played a highly distinguished role in the courts of noblemen. Breeders of Polish Half Bred horses were often counted among the elite. Currently, horses raised in most private stables are enclosed in stalls, without pastures or even paddocks. Therefore it is important that animals obtained from true breeders, who value the horses above all else, should be used for breeding. A good, healthy, proven horse is worth its price, which is not always low. Horse breeding today is often unprofitable due to 'pseudo-breeding', which lowers prices by reducing sales. It should be kept in mind, however, that one competent breeder is able to meet the demands of even a dozen riders or more (Budzyński et al. 1989; Kaproń et al. 2004; Czarnota 2008, 2014).

Corresponding author - Adres do korespondencji: Katarzyna Andraszek, Departament of Genetics and Horse Breeding, Siedlce University of Natural Sciences and Humanities, Bolesława Prusa 14, 08-110 Siedlce, Poland, e-mail: katarzyna.andraszek@uph.edu.pl 
The origins of the consolidation of the Malopolski horse type date back to the 17th century, when Oriental stallions began to have an increasingly strong effect on the horse population in Poland. This process was most evident in the Małopolska region. The dominant influence of Oriental stallions continued throughout the 17th and 18th centuries and the first half of the 19th century. Beginning in the second half of the 19th century the influence of Thoroughbred horses began to be evident, but that of Oriental horses was still very strong. Due to the mutually penetrating currents of Arabian and Thoroughbred blood, half-bred Arabian horses became the dominant type of horse in the Malopolska region. The term 'Malopolski Horse Breed' appeared on 27 December 1962 in a Regulation by the Ministry of Agriculture on the maintenance of herd books. A year later volume I of the Malopolski Horse Studbook was published. The purpose of this measure was to catalogue the population of warmblood horses associated with the Małopolska region of that time. These horses were genetically and phenotypically very distinct from half-bred horses from other regions of Poland (Kaproń et al. 2004; Tomczyk-Wrona 2006).

Horses of this breed should be distinguished by high fertility, longevity, very good feed conversion, resistance to disease and poor living conditions, endurance, and a predisposition for long, off-road riding in difficult conditions. The preferred coat colours are bay and grey; roan is unacceptable. At the age of three years the horse's measurements should be as follows: mares - about 157-165 cm tall at the withers, cannon bone circumference about 20.0-21.0 cm; stallions - about 160-168 cm tall at the withers, cannon bone circumference about $21.0-22.0 \mathrm{~cm}$ (Kaproń et al. 2004; Tomczyk-Wrona 2006).

Malopolski horses, in comparison with other sport horses, have made little progress, and thus better adapted horses are more often chosen for competitive aims. Further improvement of Malopolski horses using thoroughbred and half-bred blood is in this case undesirable, due to the exuberant temperament and considerable feed requirements of these horses. Another problem is that such sport horses usually fall into the hands of less experienced equestrians, who do not devote enough time to them and lack the means to provide professional training. Unfortunately, such 'recreationists' make up the vast majority of those using Malopolski horses (Kulisa et al. 2000; Kordalski 2004a, b; Jezierski 2010; Kordalski et al. 2010).

The anonymous author of the article: Małopolskie w niebezpieczeństwie (Malopolski horses in danger), published in the monthly Kon Polski (2009), suggests that the field of Malopolski horses continues to decline. This problem results from a direction of breeding in which a horse of oriental blood is transformed into a sport horse. The offspring of thoroughbred and French Anglo-Arabian sires were rather difficult to handle, which led to reduced demand among amateur riders. There is little talk of the Malopolski horse either in agritourism and agriculture or in competitive sport. Somewhere along the way, due to ill-considered pairings, the oriental beauty and image of the Malopolski horse was lost. Today's Malopolski horses are unsuitable for the typical amateur. Performance tests are tailored to breeds with outstanding locomotor and jumping mechanics, and unfortunately Malopolski horses, which are covered by a genetic resources conservation programme, are not able to meet the demands associated with sport (Kaproń et al. 2004; Małopolskie w niebezpieczeństwie 2009; Krupiński and Jezierski 2011; Tomczyk-Wrona 2011a, b). 
Today's breeding of Malopolski horses is oriented towards production of sport horses. However, the Malopolski horse should not only be improved for sport purposes, but should constitute an integral element of recreation, amateur sport and agritourism. Large-scale amateur riding constitutes an alternative for sport horses (Fedorski 2007; Jezierski 2010).

Native breeds of horses add to the attraction of rural areas, particularly with respect to agritourism. According to EU priorities, it is horses bred for amateurs that are profitable and have a future, and the aim of these priorities is to bridge the gap between smaller horses and large, robust sport horses. This is the task of breeders of "old-type” Malopolski horses covered by the genetic resources conservation programme (Budzyński et al. 1989; Budzyński and Rudziński 2002; Tomczyk-Wrona 2006). Subsidies granted to breeders of „old-type” Malopolski horses, through their participation in the conservation programme, are meant to compensate for the reduced prices of riding horses (Krupiński and Jezierski 2011). In order to return to the original Old Polish-Oriental form, only Malopolski stallions, painstakingly selected for appearance and origin, should be used for breeding, while mating with French Anglo-Arabs should be avoided (Kulisa et al. 2000; Kordalski 2006). The best field of Malopolski horses consists of the offspring of purebred stallions such as Etat or Elsing (Wierzbicka-Maciejewska 2002; Drewka et al. 2011). Unfortunately, the launch of a protection programme for native breeds, which include the Malopolski breed, has led some breeders to treat the subsidies as a source of income, so that individuals of increasingly poor value have begun to appear. The resources conservation programme does not allow mares to be mated with thoroughbred stallions. The use of half-bred Arabian Shagya horses, which played an active role in the history of Malopolski horses, is also prohibited (Kulisa et al. 2000; Kordalski 2008; Kaproń et al. 2013).

The decline in the Malopolski horse population has also been caused by economic and social factors, mainly the reduction in breeding of these horses in rural areas. In the Lublin and Kielce regions there is a small group of old horse enthusiasts. It is important to fully appreciate field breeding, because its collapse would limit the usefulness of stallion depots. Today's breeders of Malopolski horses are more oriented towards the "cult" of the breed than towards business, as the costs of maintaining the animal for up to 3-4 years exceed its worth (Kordalski 2003, 2004a; Cześnik 2009).

The Malopolski horse is also poorly perceived abroad, and literal translations of the name cause it to be seen as a 'small Polish horse'. The problem is manifested in the choice of sport horses, as mentioned above. If Polish competitors were to choose these horses, it is likely that today we would be able to speak of them as equally well-known around the world as the Trakehner breed. Moreover, the many amateur equestrians have little understanding of the value and assets of Malopolski horses. In order to raise the value of these horses on a global scale, radical marketing measures must be taken, including changing the name from 'Malopolski horse' to 'Polish Anglo-Arabian horse'. When the first studbook was created, the horses registered in it were considered to be half-bred Anglo-Arabians, i.e. Malopolski horses. Today's studbook is divided into Anglo-Arabians of the sport type, Anglo-Arabians of the oriental type, and horses of the Furioso-Przedświt type. Today the world talks mainly of French Anglo-Arabs, and by reaching back to our traditions we could restore the greatness of the Polish Anglo-Arab, known and valued not only in Poland or in Europe, but all over the world (Budzyński and Rudziński 2002; PZHK 2005; Kordalski 2010). 


\section{THE POLISH CHAMPIONSHIPS FOR YOUNG HORSES}

The future direction of breeding of Malopolski horses can, and even should be analysed on the basis of the achievements of Malopolski horses in the Polish Championships for Young Horses. This competition, apart from its significance in sport, also plays a role in breeding.

The first studs to focus their breeding programme on production of sport horses were Moszna, Nowelice, Liski, Rzeczna, Pruchna-Ochaby and Nowa Wioska, which led to the use of stallions with jumping abilities. However, when we compare breeding of sport horses in our country to Western Europe in the 20th century, we find a gap of about 40-50 years. In order to catch up we need to consistently apply proven breeding methods, including the proper choice of individuals, appropriate training, and the selection which is integral to breeding. This is the main factor supporting the results achieved in the countries dominating in the breeding of sport horses. Most valued are the individuals that achieve the best results in organized championships and performance testing, which raise the financial value of the animals, contribute to promotion of the parents, and increase the breeding value of the father of the highly valued individual. Following the example of the leading countries in equestrian sports, such as Ireland, Germany, France, Belgium and Sweden, a special methodology for the Polish Championships for Young Horses was established (Budzyński and Rudziński 2002; Jończyk 2004; Byszewski 2009; Gibała 2011; Sondij 2011).

Unofficially, the first such competition in the discipline of eventing took place in 1990 in Biały Bór. A show jumping competition for 5- and 6-year-old horses was held in 1992, on the initiative of Szaszkiewicz and Koziarowski, and again in 1992-1993, thanks to Byszewski in Moszna. The year 1994 saw the formation of the Sport Horse Breeders Section under the patronage of the Polish Horse Breeders Association (PZHK) and the Polish Equestrian Federation (PZJ), whose purpose was to supervise and organize championships for young horses. The problem was that the Ministry of Agriculture did not treat like performance testing, so they were not subsidized. The Agricultural Property Agency, seeing the potential of the Polish Championships for Young Horses, offered to finance this activity and continues to do so, on the condition that the competition should take place at a facility supervised by the Agency. The following locations were established: dressage - Stallion Depot Książ, jumping - Stallion Depot Łąck, eventing - Stallion Depot Biały Bór, and driving - Bogusławice Stud (the last of these was moved to the Pępowo Stud in Gogolewo two years ago). The Polish Championships for Young Horses (MPMK) allowed stallions to be officially registered in studbooks. Over time the locations where the competitions take place have changed several times and the programme and the judging rules have been modified and improved. Initially the jumping competitions were judged openly and individually and the results were averaged. Currently horses are evaluated by a three-person panel of judges and the score is determined collectively. Judges from abroad have been invited to express their opinion so that the results would appear more credible. In this case of eventing, which requires more decisive measures, improvements are continually introduced. According to statistics, eventing is the most popular discipline for Polish horses, but we should also remember dressage, in which an increasing number of Polish-bred horses start from year to year. Thanks to the thriving operation of this championship, for several years it has been possible to evaluate outstanding mares and stallions, which should be used by breeders to produce the best possible individuals for competitive sports (Byszewski 2009). 
The Polish Championships for Young Horses are for horses aged 4-7 years. The study evaluated the percentage of Malopolski horses among all Polish breeds of starters in the Championship during the period from 2010 to 2015. The horses are assessed in the following competitions: show jumping, single driving, dressage, eventing and endurance riding.

\section{0}

- show jumping: participation in all age groups about $4.30 \%$,

- driving: participation in all age groups about $8.30 \%$,

- dressage: participation in all age groups about $11 \%$,

- eventing: participation in all age groups about $35.80 \%$,

- endurance riding: participation in all age groups $0 \%$.

The total percentage of Malopolski horses in MPMK in five disciplines in 2010 was about $11.90 \%$.

\section{1}

- show jumping: participation in all age groups about $5 \%$,

- driving: participation in all age groups about $4.80 \%$,

- dressage: participation in all age groups about $6.90 \%$,

- eventing: participation in all age groups about $25.80 \%$,

- endurance riding: participation in all age groups $10 \%$.

The total percentage of Malopolski horses in MPMK in five disciplines in 2010 was about $10.5 \%$.

\section{2}

- show jumping: participation in all age groups about $4.50 \%$,

- driving: participation in all age groups about $3.70 \%$,

- dressage: participation in all age groups about $19.20 \%$,

- eventing: participation in all age groups about $30.70 \%$,

- endurance riding: participation in all age groups $0 \%$.

The total percentage of Malopolski horses in MPMK in five disciplines in 2010 was about $11.6 \%$.

\section{3}

- show jumping: participation in all age groups about $4.10 \%$,

- driving: participation in all age groups $0 \%$,

- dressage: participation in all age groups about $0 \%$,

- eventing: participation in all age groups about $35.10 \%$,

- endurance riding: participation in all age groups $0 \%$.

The total percentage of Malopolski horses in MPMK in five disciplines in 2010 was about $7.80 \%$.

\section{4}

- show jumping: participation in all age groups $0 \%$,

- driving: participation in all age groups about $0 \%$,

- dressage: participation in all age groups about $2 \%$,

- eventing: participation in all age groups about $16.90 \%$,

- endurance riding: participation in all age groups $14.80 \%$.

The total percentage of Malopolski horses in MPMK in five disciplines in 2010 was about $6.70 \%$.

\section{5}

- show jumping: participation in all age groups about $2.90 \%$,

- driving: participation in all age groups $0 \%$,

- dressage: participation in all age groups $0 \%$, 
- eventing: participation in all age groups about $40.50 \%$,

- endurance riding: participation in all age groups $4.76 \%$.

The total percentage of Malopolski horses in MPMK in five disciplines in 2010 was about $9.60 \%$.

Table 1. Percentage of Malopolski horses in the MPMK in 2010-2015

Tabela 1. Udział koni małopolskich w MPMK w latach 2010-2015

\begin{tabular}{lc}
\hline $\begin{array}{l}\text { Year } \\
\text { Rok }\end{array}$ & $\begin{array}{c}\text { Total percentage } \\
\text { Udział [\%] }\end{array}$ \\
\hline 2010 & 11.90 \\
2011 & 10.50 \\
2012 & 11.60 \\
2013 & 7.80 \\
2014 & 6.70 \\
2015 & 9.60 \\
Total - Razem & 9.68 \\
\hline
\end{tabular}

From 2010 to 2015, Malopolski horses accounted for $9.70 \%$ of all Polish breeds starting in the MPMK.

Table 2. Percentage of Malopolski horses in MPMK in 2010-2015 broken down by sex Tabela 2. Udział koni małopolskich w MPMK w latach 2010-2015, z uwzględnieniem płci

\begin{tabular}{lccc}
\hline $\begin{array}{l}\text { Year } \\
\text { Rok }\end{array}$ & $\begin{array}{c}\text { Percentage of stallions } \\
\text { Udział ogierów [\%] }\end{array}$ & $\begin{array}{c}\text { Percentage of mares } \\
\text { Udział klaczy [\%] }\end{array}$ & $\begin{array}{c}\text { Percentage of geldings } \\
\text { Udział wałachów[\%] }\end{array}$ \\
\hline 2010 & 57.10 & 28.60 & 14.30 \\
2011 & 70.60 & 11.80 & 17.60 \\
2012 & 40.00 & 20.00 & 40.00 \\
2013 & 36.40 & 36.40 & 27.20 \\
2014 & 50.00 & 20.00 & 30.00 \\
2015 & 31.00 & 46.00 & 23.00 \\
Total - Razem & 47.50 & 27.10 & 25.40 \\
\hline
\end{tabular}

Table 3. Percentage of Malopolski horses in MPMK in 2010-2015 broken down by percentage of thoroughbred blood

Tabela 3. Udział koni małopolskich w MPMK w latach 2010-2015, z uwzględnieniem dolewu pełnej krwi angielskiej

\begin{tabular}{lcc}
\hline $\begin{array}{l}\text { Year } \\
\text { Rok }\end{array}$ & $\begin{array}{c}\text { Horses with over } 50 \% \\
\text { thoroughbred blood } \\
\text { Konie powyżej } 50 \% \text { xx [\%] }\end{array}$ & $\begin{array}{c}\text { Horses with under } 50 \% \\
\text { thoroughbred blood } \\
\text { Konie poniżej } 50 \% \text { xx [\%] }\end{array}$ \\
\hline 2010 & 61.90 & 38.10 \\
2011 & 64.70 & 35.30 \\
2012 & 80.00 & 20.00 \\
2013 & 91.00 & 9.00 \\
2014 & 70.00 & 30.00 \\
2015 & 69.20 & 30.80 \\
\hline
\end{tabular}

Among Polish-bred horses Polish Half Bred individuals are the most popular choice, but Malopolski horses have started relatively frequently in the discipline of eventing, where they have often achieved very good results. As regards the choice of sex, stallions are clearly dominant, mainly due to evident economic factors. Obviously a stallion which has achieved satisfactory results in sport automatically gains in value, and interest in its semen grows among breeders aspiring to obtain offspring of the highest possible quality. We can also see that among horses starting in the MPMK the percentage of thoroughbred blood in most individuals is over $50 \%$. 
Contemporary demand in horse breeding is for production of riding horses for all types of use in sporting disciplines and active recreation, with a height of 155 to $165 \mathrm{~cm}$ for mares and 160 to $170 \mathrm{~cm}$ for stallions. Assets listed in breed standards include reproductive efficiency, longevity, economic feed conversion, an undemanding nature, resistance to disease and poor conditions, and a predilection for work (PZHK 2005).

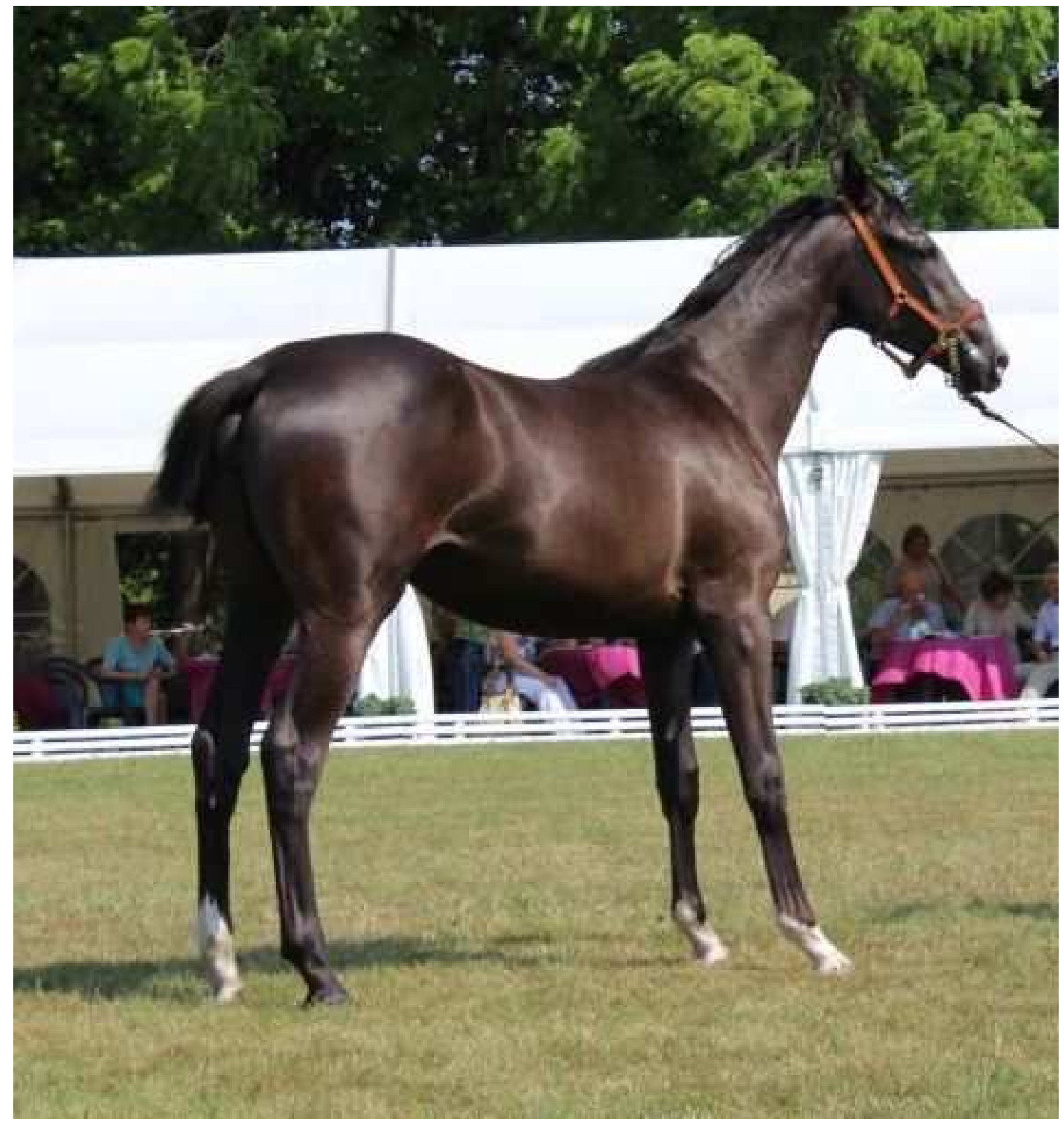

Fig. 1. The mare Atlanta (Małopolski Horse Junior Show, Białka 2015) - photo Karolina Wilczyńska Ryc. 1. Klacz Atlanta (Młodzieżowy Czempionat Koni Małopolskich, Białka 2015) - fot. Karolina Wilczyńska

The Genetic Resources Conservation Programme for the Malopolski Breed, introduced in 2005, is a response to three fundamental threats to breeding of Malopolski horses: declining numbers, mating with non-oriental breeds, and socioeconomic conditions, mainly in south-eastern Poland. An additional factor supporting this undertaking is generational tradition, 
which owing to the programme will be further cultivated through the rational use of oriental blood. The main objective set by the creators of the project is to consolidate the Malopolski horse as a Polish half-bred Anglo-Arab with a defined genotype and phenotype promoting its individuality and specific character. The Malopolski horse should play the role of a mount with possibilities for use in driving, mainly within agritourism. These horses should be used in strictly defined sport disciplines, mainly eventing and driving (Kaproń et al. 2004; PZHK 2005; Kaproń 2007; Tomczyk-Wrona 2011a,b; Polasik et al. 2015).

Attention has also rightly been drawn to the problem of the creation of a half-bred jumping horse from the Malopolski horse. Half-bred horses should jump, while Malopolski horses should be used in agritourism and trail riding, for which they were created. Malopolski horses have little chance to distinguish themselves in sport in comparison with sport horses that have undergone selection for years (Cześnik 2009; Kordalski 2010; Polasik et al. 2015).

\section{CONCLUSIONS}

Malopolski horses are an underappreciated breed of horse in our country, to say nothing of Europe or further regions of the world. Only true enthusiasts are able to perceive the greatness of this breed. Polish horse breeding was once famous for producing outstanding individuals, but this cannot be said today. We may hypothesize that this is mainly due to the economy, which influenced the directions taken in breeding for many years. This was already the case during the time of the nobility, in which the need arose for light, sturdy saddle horses with a considerable measure of oriental horse traits, and again during the Partitions, an extremely difficult period for the country, when breeding was focused on the production of horses for military use, and again during World War II, which saw a demand for horses for use in agriculture and transport. Breeders even resorted to desperate measures such as attempts to cross Malopolski horses with Silesian or Trakehner horses, which did not lead to breeding success. Many breeders struggle today with the problem of breeding horses for the purposes of sport, which places increasing demands on riding horses. But would it not be more rational to plan a strategy focused mainly on recreation, and on equestrian sports only in a limited scope? The vast majority of horses that do not meet the conditions of skilled riders end up with amateurs who cannot cope with these temperamental and difficult companions.

The analyses of the lists of starters in the Polish Championships for Young Horses confirm that the proportion of Malopolski horses starting in Championships during the years covered by the study is under $10 \%$. Among Polish-bred horses the most popularly chosen individuals are Polish Half Bred, but Malopolski horses have started relatively often in the equestrian discipline of eventing, where they have often achieved very good results.

As regards the choice of sex, stallions are clearly dominant, mainly due to evident economic factors. Obviously a stallion which has achieved satisfactory results in sport automatically gains in value, and interest in its semen grows among breeders aspiring to obtain offspring of the highest possible quality. We can also see that among horses starting in the MPMK the percentage of thoroughbred blood in most individuals is over $50 \%$.

There are currently many state studs and private breeders engaged in the breeding, or more accurately raising, of Malopolski horses. The focus of activity chosen by breeders has changed over the years, mainly due to economic conditions, as well as social ones. The many years of 
work by breeders on the Malopolski breed represent an invaluable achievement of material culture. Therefore this tradition must be continued by improving the traits and preserving the form of the original Malopolski horse.

\section{REFERENCES}

Budzyński M., Rudziński K. 2002. Cudze chwalicie... [The grass is greener...]. Koń Pol. 37(5), 48-49. [in Polish]

Budzyński M., Byszewski W., Sikora C., Słomka Z., Sołtys L. 1989. Konie małopolskie. Warszawa, Wydaw. PWN. [in Polish]

Byszewski W. 2009. Słów kilka o MPMK [A few words about MPMK]. Hod. Jeździec 7, 12-15. [in Polish]

Czarnota K. 2008. Hodować każdy może? [Anyone can raise horses?]. Koński Targ 11. [in Polish]

Czarnota K. 2014. Czartoria kraina Kuhailana. Poznań, Wydaw. Zysk i Ska. [in Polish]

Cześnik E. 2009. Uwiedzeni przez konie małopolskie [Seduced by Malopolski horses]. Hod. Jeździec 7 , 36-37. [in Polish]

Drewka M., Skoczkowski J., Kubacki S., Monkiewicz M., Święcicka N., Zawiślak J., Gulda D. 2011. Klacz Emerycha - wybitna przedstawicielka rasy małopolskiej [The mare Emerycha - a distinguished representative of the Malopolski breed]. Prz. Hod. 7, 25-28. [in Polish]

Fedorski J. 2007. Dzieje, teraźniejszość i wizja [History, the present and a vision]. Koński Targ 9, 4-7. [in Polish]

Gibała M. 2011. Znaczenie ogierów w hodowli koni rasy małopolskiej [The importance of stallions in Małopolski horse breeding]. Wiad. Zootech. 49, 85-87. [in Polish]

Jezierski T. 2010. Jest nadzieja - ale na co? [There is hope - but for what?]. Koń Pol. 45(4), 8-12. [in Polish]

Jończyk A. 2004. Furioso-Przedświty [Furioso-Przedświty]. Hod. Jeździec 2, 24-25. [in Polish]

Kaproń M. 2007. Uwagi na temat współczesnej hodowli koni małopolskich [Notes on contemporary breeding of Malopolski horses]. Koński Targ 7, 24-26. [in Polish]

Kaproń M., Tomczyk-Wrona I., Kordalski K., Jaszczyńska M., Cześnik E. 2004. Program hodowlany ochrony zasobów genetycznych koni rasy małopolskiej. Kraków-Balice, Inst. Zoot. [in Polish]

Kaproń M., Sidorowicz K., Dudek E. 2013. Program ochrony zasobów genetycznych koni rasy małopolskiej - krytycznie [Genetic resources conservation programme for Malopolski horses]. Koński Targ 6, 44-48. [in Polish]

Kordalski K. 2003. Powrót do korzeni [A return to roots]. Koń Polski 38(3), 34-35. [in Polish]

Kordalski K. 2004a. O koniach małopolskich słów kilka [A few words on Malopolski horses]. Koń Polski 39(1), 34-36. [in Polish]

Kordalski K. 2004b. Za mało krwi polskiej! [Too little Polish blood!]. Koń Polski 39(11), 34. [in Polish]

Kordalski K. 2006. Quo vadis koniu małopolski? [Quo vadis Malopolski horse?]. Koń Pol. 41(4), 56-57. [in Polish]

Kordalski K. 2008. Konie małopolskie a program ochronny [Malopolski horses and the conservation programme]. Koń Pol. 43(9), 62-64. [in Polish]

Kordalski K. 2010. Jeszcze o małopolskich [More on Malopolski horses]. Koń Pol. 45(5), 14-15. [in Polish]

Kulisa M., Pieszka M., Luszczyński J., Ciuraszkiewicz G. 2000. Wpływ pełnej krwi angielskiej i czystej krwi arabskiej na hodowle koni małopolskich [The influence of Thoroughbred and Arabian blood on breeding of Malopolski horses]. Folia Univ. Agric. Stetin., Ser. Zootech. 40, 237-247. [in Polish]

Krupiński J., Jezierski T. 2011. Czy ochrona zasobów genetycznych koni może szkodzić hodowli? [Can genetic resources conservation of horses hurt breeding?]. Wiad. Zootech. 1, 67-71. [in Polish]

Małopolskie w niebezpieczeństwie [Malopolski horses in danger]. 2009. Koń Pol. 44(9), 62. [in Polish] 
Polski Związek Hodowców Koni 2005. Program hodowli koni rasy małopolskiej. Warszawa, Wydaw. Matrix. [in Polish]

Polasik D., Pikuła R., Gawlik J., Ochman J., Terman A. 2015. Analysis of the myostatin gene (MSTN) polymorphism in four breeds of horses. Folia Pomer. Univ. Tech. Stetin. 320(35)3, 81-86.

Sondij F. 2011. Hodowla koni rasy małopolskiej - rys historyczny i sytuacja aktualna [Breeding of małopolski horses - outline of the history and present situation]. Wiad. Zootech. 2, 25-30. [in Polish]

Tomczyk-Wrona I. 2006. Ochrona zasobów genetycznych koni w ramach Programu Rozwoju Obszarów Wiejskich [Conservation of horse genetic resources as part of the Rural Development Plan]. Wiad. Zootech. 4, 21-27. [in Polish]

Tomczyk-Wrona I. 2011a. Realizacja i popularyzacja programów ochrony zasobów genetycznych koni w roku 2010 [Implementation and popularization of horse genetic resources conservation programmes in 2010]. Wiad. Zootech. 1, 61-66. [in Polish]

Tomczyk-Wrona I. 2011b. Zakres ochrony zasobów genetycznych koni rasy małopolskiej w ramach programu rolno-środowiskowego [Scope of the Małopolski horse genetic resources conservation as part of the agri-environmental programme]. Wiad Zootech. 1, 73-84. [in Polish]

Wierzbicka-Maciejewska M. 2002. Jeszcze o synku Elsinga [More on Elsing's son]. Koń Pol. 37(2), 16-7. [in Polish]

Abstract. Many horse breeders currently face the problem of breeding which is oriented towards the purposes of sport, which places increasing demands on riding horses. But would it not be more rational to plan a strategy focused primarily on recreation, as well as on equestrian sports in a limited scope? The vast majority of horses that do not meet the conditions of qualified riders end up with amateurs who cannot cope with these temperamental animals. Using information obtained from the lists of starters in the Polish Championships for Young Horses (MPMK) from 2010-2015, the study evaluated the percentage of Malopolski horses among all Polish breeds of starters and analysed the achievements of Malopolski horses, broken down by sex and by the percentage of thoroughbred blood in the individuals. The number of Malopolski horses starting in the Polish Championships for Young Horses is just under 10\%, having remained at an even level during the six years analysed. The lowest percentage of Malopolski horses was noted in 2014, at $6.7 \%$, but a year later it increased to $9.6 \%$. The many years of breeders' work on the Malopolski breed represent an invaluable achievement of Polish material culture. Therefore this tradition should be continued by improving the traits and preserving the form of the original Malopolski horse. This improvement must be based on excellent material supported by breeding work in the public and private sector. 